\title{
Physical activity as measured by accelerometry in children receiving growth hormone
}

Citation for published version (APA):

Hoos, M. B., Westerterp, K. R., Kuipers, H., Schuwirth, L. W. T., \& Gerver, W. J. (2004). Physical activity as measured by accelerometry in children receiving growth hormone. Acta Paediatrica, 93(10), 13071311. https://doi.org/10.1111/j.1651-2227.2004.tb02928.x

Document status and date:

Published: 01/01/2004

DOI:

10.1111/j.1651-2227.2004.tb02928.x

Document Version:

Publisher's PDF, also known as Version of record

Document license:

Taverne

Please check the document version of this publication:

- A submitted manuscript is the version of the article upon submission and before peer-review. There can be important differences between the submitted version and the official published version of record.

People interested in the research are advised to contact the author for the final version of the publication, or visit the DOI to the publisher's website.

- The final author version and the galley proof are versions of the publication after peer review.

- The final published version features the final layout of the paper including the volume, issue and page numbers.

Link to publication

\footnotetext{
General rights rights.

- You may freely distribute the URL identifying the publication in the public portal. please follow below link for the End User Agreement:

www.umlib.nl/taverne-license

Take down policy

If you believe that this document breaches copyright please contact us at:

repository@maastrichtuniversity.nl

providing details and we will investigate your claim.
}

Copyright and moral rights for the publications made accessible in the public portal are retained by the authors and/or other copyright owners and it is a condition of accessing publications that users recognise and abide by the legal requirements associated with these

- Users may download and print one copy of any publication from the public portal for the purpose of private study or research.

- You may not further distribute the material or use it for any profit-making activity or commercial gain

If the publication is distributed under the terms of Article $25 \mathrm{fa}$ of the Dutch Copyright Act, indicated by the "Taverne" license above, 


\title{
Physical activity as measured by accelerometry in children receiving growth hormone
}

\author{
MB Hoos ${ }^{1}$, KR Westerterp ${ }^{2}$, H Kuipers ${ }^{3}$, L Schuwirth $^{4}$ and W-JM Gerver ${ }^{1}$ \\ Departments of Paediatrics ${ }^{1}$, Human Biology ${ }^{2}$, Movement Sciences ${ }^{3}$ and Department of Educational Development and Research ${ }^{41}$, \\ University of Maastricht, Maastricht, The Netherlands
}

\begin{abstract}
Hoos MB, Westerterp KR, Kuipers H, Schuwirth L, Gerver WMJ. Physical activity as measured by accelerometry in children receiving growth hormone. Acta Pædiatr 2004; 93: 1307-1311. Stockholm. ISSN 0803-5253 Aim: Parents of children treated with growth hormone $(\mathrm{GH})$ frequently report to the paediatrician
that their children have become more physically active. In the present study, activity patterns of
GH-treated children were measured and compared to those of healthy controls. Methods: Subjects
were 25 children at the start of GH treatment (age $8.4 \pm 2.6 \mathrm{y}$ ) and 19 age- and gender-matched
controls (age $8.8 \pm 3.2 \mathrm{y}$ ). Physical activity was assessed with a tri-axial accelerometer for move-
ment registration over two separate 2 -wk intervals, one before the start of GH treatment and one
2 wk after the start of treatment. GH-treated subjects were categorized as poor responders (change
in height over $1 \mathrm{y}<0.7 \mathrm{SDS}, n=15$ ) or good responders (change in height over $1 \mathrm{y}>0.7 \mathrm{SDS}$,
$n=10$ ). Results: Before therapy, good responders showed a significantly lower physical activity
compared to healthy controls, spending significantly less time on high-intensity activities. This
difference disappeared 2 wk after the start of therapy. Physical activity in poor responders was not
significantly different from controls before and after 2 wk of GH therapy.
\end{abstract}

Conclusion: Children who respond well to GH therapy (change in height $>0.7$ SDS) showed a reduced amount of physical activity before therapy, which was normalized after 2 wk of GH therapy.

Key words: Growth hormone deficiency, physical activity intensity, physical activity frequency, Tracmor

MB Hoos, University of Maastricht, Department of Paediatrics, PO Box 5800, 6202 AZ Maastricht, The Netherlands (Tel. +31 433874297, fax. +31 433875246, e-mail. marije.hoos@ kg.unimaas.nl)

Since the FDA approved the use of recombinant growth hormone $(\mathrm{rGH})$ in 1985, the number of prescriptions of growth hormone has risen dramatically (1). It was no longer only severely growth hormone deficient (GHD) patients who were treated, but also children suffering from partial GHD. The eligibility of patients for $\mathrm{GH}$ treatment is decided on the basis of anthropometric parameters and endocrine testing.

In paediatric patients, growth hormone therapy is used to correct height deficit. However, it is also remarkable that parents frequently report to physicians that their child has become livelier after the start of treatment. This may be based on metabolic effects of $\mathrm{GH}$, as have been described in the literature. Gregory et al., for example, found a significant increase in basal metabolic rate (BMR) (2) and total daily energy expenditure (TDEE) in children receiving GH therapy.

An increase in TDEE can be attributed to growth as well as to increased physical activity. Possible changes in this component of TDEE can be measured by accelerometry. Accelerometers measure the occurrence and intensity of body movements. The method is easy applicable and does not interfere with the child's daily activities. Two kinds of accelerometers are distinguished: one-axial and tri-axial accelerometers. Oneaxial accelerometers measure accelerations in one direction in contrast to tri-axial accelerometers, which measure accelerations of the body in three dimensions.

Since data about physical activity patterns in children receiving GH therapy are lacking, the present study investigated the short-term effect of $\mathrm{GH}$ on spontaneous physical activity. For this purpose, the Tracmor, a triaxial accelerometer, which has been proven to be a reliable tool for the assessment of physical activity in adults (3-4) as well as in children (5), has been used. The patients were divided into two groups (good responders and poor responders), according to their response to GH therapy, to see whether the short-term changes in activity patterns were comparable between the two groups. In addition to the intensity of physical 
activity, Tracmor data have been used to calculate the fraction of time spent on a given activity at low, moderate or high levels of intensity (3-4).

\section{Methods}

\section{Subjects}

Eligibility for therapy was based solely on one or more anthropometric criteria as visible in GH-deficient patients: height SDS at start of treatment $<-2.5$ SDS, deviation from target height $>1.3$ SDS and growth in the year before treatment $>-0.25$ SDS. Additional endocrine testing was performed (arginine, clonidine and sleeping test) to measure maximum GH concentrations. Some children did not undergo all tests because they were submitted from other hospitals. The clonidine test could not be performed in one child indicated to be hypersensitive to clonidine.

To minimize the influence of environmental factors, healthy controls were selected from friends or relatives of the patients living in the same neighbourhood. They were measured simultaneously with the patients, but did not receive GH therapy. Parents and children were informed about the study and written informed consent was obtained. The study was approved by the Ethical Committee of the University Hospital Maastricht.

All patients were prepubertal by physical examination. Two control patients were already pubertal.

\section{Study design}

The Tracmor was worn twice (M1 and M2) during a 2wk period, before the start of therapy in the patients and during weeks 3 and 4 of this therapy. The children received $0.7 \mathrm{mg} \mathrm{hGH} / \mathrm{m}^{2} / \mathrm{d}$ (Humatrope ${ }^{\mathbb{R}}$ ). Two girls with Turner syndrome received $1.3 \mathrm{mg} \mathrm{hGH} / \mathrm{m}^{2} / \mathrm{d}$ (Humatrope ${ }^{\mathbb{R}}$ ), in accordance with Dutch treatment criteria. After $1 \mathrm{y}$, growth was evaluated and expressed as Z-scores (SDS) (6). The difference in SDS $\left(\mathrm{SDS}_{\text {t1year- }} \mathrm{SDS}_{\mathrm{t} 0}\right)$ was used to divide the patient group into good and poor responders. A change in SDS $>0.7$ was considered to be a good response, based on the mean response to GH therapy found in the study by Ranke et al. (7).

\section{Physical activity}

Physical activity was assessed with the help of a triaxial accelerometer for movement registration (Tracmor, Philips Research, Eindhoven, The Netherlands). The Tracmor is a small device $(7 \times 2.8 \times 0.8 \mathrm{~cm})$, which is worn on a belt at the back of the waist. The triaxial accelerometer calculates the sum of the rectified and integrated acceleration curves from the anteroposterior, mediolateral and vertical directions of the trunk. The integration period was set at $1 \mathrm{~min}$, and the final output is expressed as counts per minute (cpm) (3)

The Tracmor was worn during waking hours, except while showering and during swimming. The parents of the children recorded in a log the times when the children woke up, when they put the Tracmor on and off, and when they went to bed. If the sum of the time during which the device was worn and the duration of sleep was less than $22 \mathrm{~h}$, the day was excluded from the analysis (mean number of recorded days was 11).

Activities were defined at three intensity levels, as described before (3-4), Low-intensity, associated with an accelerometer output $\leq 200 \mathrm{cpm}$, represents lying, sitting and standing. Moderate-intensity, associated with an accelerometer output ranging from 200 to 500 $\mathrm{cpm}$, includes walking at a velocity of $1.5-2.0 \mathrm{~km} / \mathrm{h}$. High-intensity activities are associated with an accelerometer output $\geq 500 \mathrm{cpm}$. The fraction of time spent at a given intensity level was calculated as the time spent at this intensity level divided by total activity time.

\section{GH stimulation tests}

Arginine test. The arginine test was performed in the morning after an overnight fast. Arginine hydrochloride $(0.5 \mathrm{~g} / \mathrm{kg})$ was infused for $30 \mathrm{~min}$. Blood samples were taken to measure growth hormone levels at $-15,0,30$, $45,60,75,90$ and 120 min after the start of the infusion (8).

Clonidine test. The clonidine test was performed in the morning after an overnight fast. After an oral dose of clonidine $\left(0.15 \mathrm{mg} / \mathrm{m}^{2}\right.$, max. $\left.0.15 \mathrm{mg}\right)$, blood samples were taken every $30 \mathrm{~min}$ for the next $2 \mathrm{~h}$ to measure growth hormone levels (8)

Sleeping test. Because natural peaks of growth hormone secretion occur during the first hours of sleep, blood samples were taken every 10 min during the first $2 \mathrm{~h}$ of sleep to measure growth hormone levels.

\section{Statistics}

Tracmor data were expressed as counts/min, mean Tracmor counts per day were divided by the time during which the device was worn, to correct for possible differences in activity time. For each group of children, a paired $t$-test was used to see if there was a significant difference in the Tracmor data before and after 2 wk of therapy. The treated groups were compared with each other and with the control group using an independent $t$ test.

\section{Results}

Patient characteristics before and after $1 \mathrm{y}$ of $\mathrm{GH}$ therapy are given in Table 1 . The mean growth response after $1 \mathrm{y}$ for the entire growth hormone treatment group $(n=25)$ was +0.59 SDS $( \pm 0.45)$, while the change in SDS in the control group was $+0.02( \pm 0.21)$. On the 
Table 1. Patient characteristics.

\begin{tabular}{lccc}
\hline & Controls $^{\mathrm{a}}$ & Poor responders & Good responders \\
\hline Height before therapy (cm) & $130.5(19.9)$ & $123.2(13.9)$ & $105.1(9.6)$ \\
Height 1 y after therapy (cm) & $135.2(19.4)$ & $130.3(14.2)$ & $116.0(10.4)$ \\
Height before therapy (SDS) & $-0.89(1.2)$ & $-2.71(0.97)$ & $-3.52(0.77)$ \\
Height 1 y after therapy (SDS) & $-0.95(1.1)$ & $-2.44(0.94)$ & $-2.41(0.83)$ \\
Weight before therapy (kg) & $28.1(11.0)$ & $23.0(6.1)$ & $15.0^{\mathrm{b}}(3.3)$ \\
Weight 1 y after therapy (kg) & $30.8(12.0)$ & $26.1(6.8)$ & $18.3(3.4)$ \\
Weight before therapy (SDS) & $-0.61(0.98)$ & $-1.92(0.79)$ & $-2.73(1.1)$ \\
Weight 1 y after therapy (SDS) & $-0.59(0.94)$ & $-1.79(0.73)$ & $-2.01(0.77)$ \\
Weight-for-height (SDS) before therapy & $-0.17(1.05)$ & $0.25(1.11)$ & $-1.02(1.52)$ \\
Weight-for-height (SDS) after therapy & $0.09(1.37)$ & $0.15(0.73)$ & $-1.14(1.61)$ \\
GH concentration, arginine test (mU/l) & & $23.1(11.1)(n=15)$ & $17.0(8.4)(n=10)$ \\
GH concentration, clonidine test (mU/l) & & $38.2(29.2)(n=13)$ & $31.5(13.1)(n=7)$ \\
GH concentration, sleeping test (mU/l) & & $18.3(9.4)(n=15)$ & $14.0(12.2)(n=7)$ \\
\hline
\end{tabular}

${ }^{\mathrm{a}}$ Anthropometric data of one control subject after $1 \mathrm{y}$ of therapy were missing.

${ }^{b}$ To calculate weight data, one patient was excluded because of an abnormal increase in weight during the first year of therapy.

Values are means (SD).

basis of the response to GH therapy, three groups could be distinguished: 1$)$ control group $(n=19)$ (mean age $8.8 \pm 3.2 \mathrm{y})$; 2) patient group with a response to $\mathrm{GH}$ therapy $<0.7$ SDS/y $(n=15)$ (mean age $9.7 \pm 2.4$ y); 3) patient group with a response to $\mathrm{GH}$ therapy $>0.7$ SDS/y $(n=10)$ (mean age $6.5 \pm 1.7 \mathrm{y}$ ).

Of the 25 children who started GH therapy, 17 had a height below -2.5 SDS (9 were good responders), 21 deviated more than 1.3 SDS from their target height (10 were good responders) and 8 children (6 were good responders) showed a deviating growth chart.

Although the mean age of the two patient groups did not differ significantly from that of the controls, the children with a poor response to $\mathrm{GH}$ therapy were significantly older than the good responders $(9.7 \pm 2.4$ vs $6.5 \pm 1.7 \mathrm{y} ; p<0.01$ ). The number of recorded days did not significantly differ between the two measurements periods.

As can be seen in Table 2, the number of Tracmor counts/min before the start of the GH therapy was significantly lower in the good responders than in the controls $(p<0.05)$. After 2 wk of therapy, this difference had disappeared, because of a significant increase in the number of counts/min among the good responders $(p<0.05)$ (Table 2).

The proportion of time the three groups spent on low-, moderate- and high-intensity activity is listed in Table 2. This shows that before therapy, good GH therapy responders spent less time on high-intensity activities than controls and poor responders $(p<0.05$ and $p<0.01$, respectively). After 2 wk of GH therapy, there was no longer a significant difference between the three groups. Good GH therapy responders showed a significant increase in high-intensity activities $(p<0.05)$. Tracmor data of poor GH responders did not significantly differ from controls before as well as after start of therapy. Excluding the Turner patients did not influence the outcome of the results.

A comparison of the two patient groups in terms of the maximum growth hormone values found during the endocrine tests revealed no significant difference between the good and poor responders as regards the

Table 2. Tracmor data output of three subject groups: controls, poor GH responders (change in height $<0.7$ SDS) and good GH responders (change in height $>0.7$ SDS)

\begin{tabular}{|c|c|c|c|c|c|c|c|}
\hline & \multicolumn{2}{|c|}{ Controls } & \multicolumn{2}{|c|}{ Poor responders } & \multicolumn{3}{|c|}{ Good responders } \\
\hline & M1 & M2 & M1 & M2 & M1 & & M2 \\
\hline Tracmor (counts/min) & $61^{\mathrm{a}}(17)$ & $57(17)$ & $67^{\mathrm{a}}(16)$ & $64(15)$ & $48^{\mathrm{b}}(11)$ & * & $55(12)$ \\
\hline Low activity $(\%)$ & $56(10)$ & $56(12)$ & $56(11)$ & $58(11)$ & $62(8)$ & & $58(11)$ \\
\hline Moderate activity (\%) & $25(6)$ & $25(6)$ & $23(5)$ & $23(5)$ & $25(6)$ & & $26(6)$ \\
\hline High activity $(\%)$ & $19^{\mathrm{a}}(7)$ & $19(8)$ & $21^{\mathrm{a}}(7)$ & $19(7)$ & $13^{\mathrm{b}}(5)$ & $*$ & $17(7)$ \\
\hline
\end{tabular}

M1: first measurement period, before start of GH treatment in the patients; M2: second measurement period, 2 wk after the start of GH treatment in the patients.

Values are means (SD). Tracmor data were expressed as counts/min; mean Tracmor counts per day were divided by the time during which the device was worn, to correct for possible differences in activity time.

A paired $t$-test was used to see if there was a significant difference in the Tracmor data before and after 2 wk of therapy.

* Denote within groups differences compared to baseline values $(p<0.05)$.

An independent $t$-test was used to test the difference between the three different patient groups. Lower-case letters represent between-group differences; means with different letter superscripts are significantly different $(p<0.05)$. 
maximum GH concentrations found during the sleep, arginine or clonidine tests.

\section{Discussion}

Growth hormone is known to have an anabolic effect, which is associated with increased energy expenditure (9). Although it is the general experience of paediatricians that children become more active after the introduction of GH therapy, Gregory et al. were unable to demonstrate an increase in activity. The measured increase in TDEE in their study reflected the increase in BMR (2).

In the present study, the children were divided into two groups according to their response to growth hormone therapy. Before the start of GH therapy, good GH therapy responders showed a lower number of Tracmor counts per minute and spent less time on highintensity activities. The observed difference had disappeared after $2 \mathrm{wk}$ of GH therapy. This means that children with a good response to GH therapy were less physically active than healthy controls until GH was supplemented. The lower amount of activity before start of treatment might be partly explained by an impaired erythropoiesis, as was demonstrated in GHD adults (10). Erythropoiesis increases during GH therapy, which may lead to an increase in oxygen capacity and thereby contribute to an improved exercise performance capacity (10-11). In addition, an increase in plasma volume and total blood volume, as was measured in GH-deficient adults on GH therapy $(10,12)$, might contribute to an increase in $\mathrm{VO}_{2 \max }$ (13). Another explanation might be a change in body composition, which is observed after start of GH treatment (14).

However, as the present study showed, the amount of spontaneous physical activity differed between good and poor responders. In contrast to the good responders, poor responders were comparable to controls before start of GH treatment. GH therapy did not influence their activity patterns. Probably, in these children, their retarded growth was not based on growth hormone deficiency. The present results show that additional exogenous GH therapy does not influence activity levels in these children in contrast to the good responders in which GH therapy causes an increase in growth and physical activity.

The effect of GH therapy on activity was observed over a relatively short period of time because metabolic effects of GH therapy become apparent soon after its start $(12,15)$, as was confirmed in the present study. The good responders adapted similar activity levels as their control counterparts after 2 wk of GH supplementation. However, it would have been of interest to measure physical activity after $1 \mathrm{y}$ of therapy to see if the increase in physical activity in the good responders was maintained. Unfortunately, this was not possible be- cause of practical limitations and should be the subject of future studies.

In the present study, intensity of physical activity was measured using a tri-axial accelerometer, which is a non-invasive method of measuring activity under freeliving conditions. It confirmed the increase in activity reported by some parents after the introduction of $\mathrm{GH}$ therapy. Good responders were less active than controls before the introduction of GH therapy, which was normalized $2 \mathrm{wk}$ after the start of therapy. In the poor responders group, GH therapy had no effect on activity. The increase in physical activity in responders was mainly attributable to an increase in high-intensity activities.

Acknowledgements.-We would like to thank JMJ Sijstermans and PMVM Theunissen of the Atrium Hospital Heerlen for their contributions to this study.

\section{References}

1. Grumbach KM, Bin-Abbas HS, Kaplan SL. The growth hormone cascade: progress and long term results of growth hormone treatment in growth hormone deficiency. Horm Res 1998; 49 Suppl 2: 41-57

2. Gregory JW, Greene SA, Jung RT, Scrimgeour CM, Rennie MJ. Changes in body composition and energy expenditure after six weeks' growth hormone treatment. Arch Dis Child 1991; 66: 598-602

3. Bouten CV, Verboeket-van de Venne WP, Westerterp KR, Verduin M, Janssen JD. Daily physical activity assessment: comparison between movement registration and doubly labeled water. J Appl Physiol 1996; 81: 1019-26

4. Meijer EP, Goris AHC, Wouters L, Westerterp KR. Physical activity as a determinant of the physical activity level in the elderly. Int j Obes 2001; 25: 935-9

5. Hoos MB, Plasqui G, Gerver WJ, Westerterp KR. Physical activity level measured by doubly labeled water and accelerometry in children. Eur J Appl Physiol 2003; 89: 624-6

6. Gerver WJM, de Bruin R. Paediatric morphometrics, a reference manual. 2nd extended ed. Maastricht: Universitaire pers Maastricht; 2001

7. Ranke MB, Guilbaud O. Growth response in prepubertal children with idiopathic growth hormone deficiency during the first two years of treatment with human growth hormone. Analysis of the Kabi Pharmacia International Growth Study. Acta Paediatr Scand 1991; Suppl 379: 109-15; Discussion 116

8. de Muinck Keizer-Schrama SMPF, Boukes FS, Oostdijk W, Rikken B. Diagnostiek kleine lichaamslengte bij kinderen [Diagnosis of short stature in children]. Alphen aan de Rijn: van Zuiden Commmunications B.V.; 1998

9. Cowan FJ, Evans WD, Gregory JW. Metabolic effects of discontinuing growth hormone treatment. Arch Dis Child 1999; 80: $517-23$

10. Christ ER, Cummings MH, Westwood NB, Sawyer BM, Pearson TC, Sonksen PH, et al. The importance of growth hormone in the regulation of erythropoiesis, red cell mass, and plasma volume in adults with growth hormone deficiency. J Clin Endocrinol Metab 1997; 82: 2985-90

11. Vihervuori E, Virtanen M, Koistinen H, Koistinen R, Seppala M, Siimes MA. Hemoglobin level is linked to growth hormonedependent proteins in short children. Blood 1996; 87: 2075-81

12. Moller J, Frandsen E, Fisker S, Jorgensen JO, Christiansen JS. Decreased plasma and extracellular volume in growth hormone deficient adults and the acute and prolonged effects of $\mathrm{GH}$ 
administration: a controlled experimental study. Clin Endocrinol (Oxf) 1996; 44: 533-9

13. Sawka MN, Convertino VA, Eichner ER, Schnieder SM, Young AJ. Blood volume: importance and adaptations to exercise training, environmental stresses, and trauma/sickness. Med Sci Sports Exerc 2000; 32: 332-48

14. Vaisman N, Zadik Z, Akivias A, Voet H, Katz I, Yair S, et al. Changes in body composition, resting energy expenditure, and thermic effect of food in short children on growth hormone therapy. Metabolism 1994; 43: 1543-8

15. Copeland KC, Nair KS. Acute growth hormone effects on amino acid and lipid metabolism. J Clin Endocrinol Metab 1994; 78: 1040-7

Received Nov. 21, 2003; revision received Mar. 2, 2004; accepted Apr. 10, 2004 